\title{
Medieval Prisons: Between Myth and Reality, Hell and Purgatory*
}

\author{
Guy Geltner
}

Princeton University

\begin{abstract}
When were medieval prisons founded? What was life inside them like? How did contemporary observers perceive them? Addressing such questions, this article brings together over a century of scholarship that undermines the traditional dating of the prison's "birth," sheds light on the tolerable realities of medieval captivity, and identifies a range of contemporary interpretations of prison life and spaces.
\end{abstract}

The creation of prisons as punitive institutions is commonly dated to the late eighteenth century, and is attributed to the influence of Enlightenment ideas about man's ability to reform his soul and the State's prerogative in implementing this process. ${ }^{1}$ The accepted chronology denies the penal role of prisons at any time earlier, at least outside ecclesiastical jurisdiction. Accordingly, the view prevails that throughout the Middle Ages prisons served as places of pre-trial custody or loci of coercion for defaulting debtors; punitive incarceration, in turn, "did not exist or represented, at best, a negligible exception."2

Perhaps the most eloquent refutation of such claims was made by Ralph Pugh in his 1968 study Imprisonment in Medieval England. Pugh began by restating what most observers of prison life (including medieval lawyers) already knew, namely, that the distinction among custodial, coercive, and penal incarceration is useful in theory, but fails to describe actual practices. Thus, to say that medieval "penology" consciously avoided incarceration would be anachronistic and misleading. Pugh then demonstrated that, even in a stricter sense, punitive imprisonment was both an articulated legal concept and a practiced penal measure in England throughout the high and late Middle Ages. ${ }^{3}$ As many other studies throughout the last century and a half have shown, the same argument can be applied to different European regions from Late Antiquity to the late Middle Ages. ${ }^{4}$

The introduction of imprisonment had a lasting impact on the organization of local justice systems. For instance, in order to implement incarceration widely, magistrates had to appropriate or construct prison facilities and install the necessary officers such as wardens, guards, and notaries, as well as provide for a variety of service-givers: coroners, carpenters, water-carriers, physicians, 
and chaplains. Moreover, city councils had to regulate the personnel's selection, fix their salaries, and develop supervisory mechanisms to monitor their conduct. This intensive activity in and around prisons was unprecedented, and in many ways set the path for modern prison administration: London's Fleet Prison, Paris's Châtelet and Florence's Le Stinche - to name only a few flagships among hundreds of contemporary institutions - continued to function for centuries to come.

Prior to the foundation of municipal prisons (with which we are mostly concerned here), incarceration was common to ecclesiastical penal practice. Ideologically opposed to bloodshed, and enabled by its relatively autonomous jurisdiction, the Church inflicted erring clerics and monks with prison sentences (sometimes known as detrusio) at least since the fourth century. ${ }^{5}$ Moreover, penitential compilations throughout the Middle Ages advocated the application of penal incarceration against laymen, but it is unclear to what extent these prescriptive texts were put into practice. In any case, many monasteries and episcopal palaces developed basic prison facilities. We know very little about life within them, but some evidence suggests that it was modeled on the monastic penitential life, including solitude, long fasts, and prayers. There is, however, no reason to believe that clerics (or, occasionally, laymen) who underwent these punishments ever took monastic vows. From the early thirteenth century, the Church was able to implement the incarceration of laymen on a wider scale than ever before through the activity of the Papal Inquisition, which often sentenced heretics to prison. ${ }^{6}$ In sum, although imprisonment remained a marginal penalty in the secular world, ecclesiastical practices certainly sowed the seeds of a bond between the prison and spiritual reform, as evinced by the modern term "penitentiary."

Another type of medieval prison was the castle dungeon, tower, gatehouse or pit, which, as a modern literary trope, still exercises much influence on the popular imagination. No doubt, feudal lords occasionally imprisoned their subjects and political enemies for the duration of a trial, as a penal measure, or simply in order to collect ransom. Conditions inside these prisons differed from place to place and varied widely according the social status of the prisoner. The available information is too scarce to gage the frequency of such practices, but the development of a hagiography of "jail-breaking saints" (headed by St. Leonard) suggests that they were common or simply infamous enough to generate these heroes. ${ }^{7}$ In general, it seems that "feudal" incarceration was intermittent; it was often applied ad personam, and never formally regulated.

Against this background, the secular municipal prisons of the late Middle Ages display several key innovations, not least among which are their careful regulation and administrative sophistication. In Florence, for instance, there were four wardens, four to six guards, a notary, a chamberlain, a physician, a chaplain, a caretaker, and two friars who attended to the prisoners' needs; as well as three different supervisory boards to monitor the officials' conduct and the inmates' welfare. The salaried staff itself lived and worked in a new 
compound - Le Stinche (founded c.1300) - probably the first purpose-built prison in Italy and one of the first in Europe. Turnovers there could exceed eight hundred inmates a year. And while most Florentine prisoners were private or public debtors, others were incarcerated for minor crimes such as theft, gambling, and bearing arms, and an even greater number for defaulting on fines assessed against them for a wide range of offenses, from fraud to violent assault. Slaves (mostly female) and children were occasionally imprisoned explicitly "pro emendare" (for correction). In a certain sense, then, Le Stinche displays some of the characteristics of modern facilities and penology. ${ }^{8}$

Regional and local studies have shown that Le Stinche was not an isolated case, a fact which renders the years $c .1250-c .1350$ a watershed period in the history of the prison. How to account for this shift? The proliferation of prison spaces across western Europe coincided with a period of intense urbanization and a growth of urban (communal) liberties. ${ }^{9}$ As a reflection of this process, throughout the thirteenth century urban space was transformed to fit a new participatory ideology: no longer exclusive to the scions of local aristocracies, political decision-making - effectively and symbolically - began to be conducted among the range of new centralized facilities: the town hall, the courtroom, the central square.$^{10}$ In the attempt to consolidate their judicial administrations, urban communes sought to confine deviants, dissidents, and criminals in the building of the prison, which the magistrates usually founded in or near the main government compound. Unlike today, then, most medieval prisons were both central and visible. ${ }^{11}$

Beyond its symbolism, however, the typical prison's location addressed some practical needs. Medieval polities rarely provided their prisoners with the range of services that are customary (and mostly free) today, such as meals, medical aid, spiritual guidance, and recreational and educational programs. Accordingly, the prison's centrality ensured that inmates - and not just the edifice - were visible and accessible. And in fact, many different people frequented these compounds: local magistrates and prosecutors, of course, but also priests, physicians, families, friends, charitable officials, business partners, and even prostitutes. Thus, medieval inmates were never fully cut off from surrounding society, which, in turn, placed a further check on the staff's conduct. ${ }^{12}$

Human traffic flowed both in and out of the prison. Just as the prison became a sine qua non of the urban landscape, so its inmates were integrated into the local human panorama. They left their cells to beg, pursued their legal affairs, and attended family events. Three or four times a year, during the major liturgical feasts, prisoners were "offered" by some governments at the local cathedral on behalf of the city. ${ }^{13}$ As their numbers grew, so did their visibility. And it is no wonder that donations to alleviate prisoners' conditions and for the release of the poorer among them peaked in that very period. According to one study, over 25 percent of Londoners' wills between 
1376 and 1531 contained bequests for the material benefit of prison inmates. ${ }^{14}$ In sum, evidence of the prisoners' social ties with the extramural world confirms that prison life in the Middle Ages was as far from its present stereotype as a "hellhole," as it was from our modern conceptions of prisons as "total" institutions. ${ }^{15}$

All this is not to argue that medieval prison life was pleasant, only that it was mostly tolerable. ${ }^{16}$ Supervision over inmates was not total, which left them free but also vulnerable. Lacking means to pay off their debts or fines, prisoners could languish for years, inflicting their families with financial ruin. Food could be scarce or unaffordable, and those who could not rely on steady supplies from outside survived on charitable offerings, sometimes as little as a loaf of bread per day. The confluence of imbalanced diets, cramped quarters, and poor hygiene meant that prisoners (somewhat like monks) were particularly prone to die in epidemics, as confirmed by their decimation during the Black Death. Violence - verbal, emotional, sexual, and physical - was arguably the greatest pain of medieval imprisonment, and often accompanied another common and illicit activity: gambling.

In contrast to the strict regimentation of time in modern prisons, medieval inmates lacked a real daily routine. Prisoners seldom worked, and diversions were scarce: visits were necessarily limited, reading material hard to come by, space for recreational activities mostly unavailable, alcohol prohibited and prostitutes rare. Financial and legal affairs could occupy some of a prisoner's time, but these were often over within several weeks, and seldom guaranteed an occasional leave. Begging outside the walls was only intermittently allowed even before certain administrations opted to employ penitential friars for this purpose. There were, of course, the daily masses and bread distributions, the weekly sermons and the supervisory committee's visits, and the city's liturgical cycle, which the inmates were well positioned to follow, however vicariously, during solemn oblations on major feasts. In general, however, medieval prison life was rather uneventful.

The allocation of inmates into wards - and these were common even among medium-sized facilities - reveals another peculiarity of medieval prisons. For such allocations were based not only on the culprit's offense, but also on his social status and available funds. In fact, the latter could often outweigh the former. Women, for instance, were usually placed together regardless of their crime. This was mostly called for by efficiency, given the small number of female inmates and the strict gender separation enforced in virtually all prisons. In more elaborate institutions, the same would apply for the sick or those deemed mentally ill. But the run-of-the-mill miscreant could choose between various wards, rated according to their level of accommodation. Simply put, one could formally improve his living conditions: better cells, better food, light, heating, bedding, etc., were normally for sale, whether the prison was leased by a private person or run by the municipality. In this way prison administrators could earn extra cash while maintaining external social distinctions. 
The wardens and guards had an enormous responsibility. And while their job was not nearly as dangerous as it is today (death among the personnel was rare in the Middle Ages), it already entailed some of the internal contradictions that characterize its modern counterpart. The staff's salaries were modest, which rendered all the more probable a temptation to provide informal services or abuse their position. Guards were occasionally involved, directly or indirectly, in smuggling prostitutes and other illicit visitors, selling wine, and generally allowing gambling and sexual relations to remain clandestine. Needless to say, not all of these activities bettered the inmates' lives, yet, to judge by the prisoners' low death rates, the rare cases of suicide, the scarcity of escapes (and medieval prisons were quite permeable) and the infrequent attacks on personnel, life in prison was far from hell on earth.

In Roman legal thought, which dominated medieval jurisprudence, incarceration was considered an illegitimate punishment - a measure "dismal to the innocent, but not harsh enough for the guilty." ${ }^{17}$ Yet, as mentioned above, punitive imprisonment was favored by the Church on account of its non-violence, and even featured as a leitmotiv - a typical "sweet inversion" - of Christian asceticism. ${ }^{18}$ Thus, the medieval imaginary of the prison was founded on a tension between misery and spiritual growth, and for nearly a millennium prisons were widely held as earthly purgatories rather than earthly hells. ${ }^{19}$ But with the proliferation of municipal prisons, this image was challenged and often modified in a variety of ways. The following section illustrates some of these instances.

The increasing recourse to incarceration in the secular world undermined the prison's traditional image as a place of penance. No longer a mere metaphor for the vita angelica, imprisonment was redefined on a civic register, since the foundation of prisons was now seen as a symbolic act of secular political autonomy. Among the Italian city-states, for instance, debates over the establishment of new prison facilities convey a proud sense of progress and civic charity. Extant deliberations of city-councils routinely emphasize the new regimes' break from their oligarchic past and the latter's alleged neglect of non-noble citizens. While such texts deliberately criticize earlier aristocratic regimes, they also illustrate how urban magistrates were interested in presenting their new prisons as formidable and yet rational, more efficient and salubrious institutions. ${ }^{20}$ Reflecting similar sentiments, chroniclers of that period approvingly described the foundation and use of local prisons ${ }^{21}$ - acts whose historical significance is echoed by the inclusion of accurate depictions of such buildings in contemporary urban landscapes. ${ }^{22}$

Late medieval descriptions and depictions of urban prisons confirm that these institutions were perceived as legitimate symbols of hard-won urban liberties. But approval was not blind, nor did contemporaries cling to the monastic trope of the prison as an earthly purgatory. Recounting the future wonders of Padua to its mythological founder, the fourteenth-century author Giovanni da Nono paused to indicate "a terrible, fetid place [within the Podestà's Palace], called Basta, where men will be placed who owe money 
to others, and almost all the criminals." It was not the only prison space Padua could boast of:

One of the [remaining ten palaces], to the west, will be called the New Prison, and it will be very strong. This palace will be divided into three parts: in one will be placed men who owe others money or who owe the commune for fines or taxes, and this part can be likened to Limbo; in the second will be those who have committed some [minor] crimes, and this can be equated to Purgatory; in the third will be placed homicides, robbers, marauders and other criminals, whose crimes are manifest, and this dark part, where no light ever penetrates, you will truly be able to liken to Hell. ${ }^{23}$

Da Nono's account reveals a more nuanced understanding of the prison, probably in light of its diverse functions. Although the traditional tie between the prison and the afterlife remained in tact, the facility's image was modified to fit the new realities of civic justice. It was time for a "bitter inversion": just as the monastery straddled the gap between an earthly purgatory and paradise, so the criminal ward of Padua's prison offered a palpable link between hell on earth and its netherworldly counterpart. To trust our author, many other inmates were in limbo or purgatory: their fate could have certainly been worse. $^{24}$

Several texts survive which purport to reflect the inmates' own experiences, and are tellingly full of harsh criticisms, sarcasm, and irony. Authors such as Dino di Tura and, later, the burlesque poets Burchiello and Francesco Berni, perceived their incarceration not as penance, but as the result of local enmities, and imaged their cells not as gateways to spiritual reform, but as corrupt dens. As the following selection shows, some authors depicted their prison as a pseudo-paradise, a perfect community of humans or a utopia, while others took a more direct route to revealing the stark realities of medieval incarceration. Jointly, these works illustrate a shift away from the customary purgatorial imagination of the prison:

Having turned it round and round

In my mind, I have conclusively concluded,

That the prison is the best place in the world.

Where can one lead a better life?

Where are happier days spent?

He is mad who complains about it.

It keeps us safe from enemies. ${ }^{25}$

Oh you who enter this enclosing,

If you look at the wretched inmates

With your mind's eye, you would say

That there is no sorrow like ours.

We are in misery, as I'll show,

To suffer heat, hunger, chill and thirst:

We were once free like you are

And we don't mind your state.

But we pray to kindle your pity 
And offer prayers to the almighty Creator

To restore our freedom soon. ${ }^{26}$

O, glorious Stinche of Florence;

Celestial place, divine place,

Worthy of a hundred-thousand reverences.

To you men come with bowed heads,

And before they climb your stairs

They stoop at your door step. ${ }^{27}$

In 1541, the Venetian poet Zanni (Giovanni) Manenti completed this shift by passing from infernal allusions to an outright identification of the prison with earthly hell. In his Dantesque voyage through Venice's justice system, Manenti dealt with the republic's prisons - whose layout dates back to the late thirteenth century - under the title "Inferno del mondo." 28 Similarly, one of the Veronese prison wards was called the Inferno. ${ }^{29}$

Despite the dominance of netherworldly imagery, some writers insisted on secularizing images of local prisons. The famous fourteenth-century novelist Franco Sacchetti based one of his tales at Le Stinche, ${ }^{30}$ and the German friar Felix Fabri, en route to the Holyland in 1484, penned the following description of the Venetian prisons:

[T] he malefactors' prisons, located under the palace's promenade, have a view of the public square, illuminated by open windows which are blocked by iron bars. Through these windows the inmates can look out, stretch their hands and converse with the nearby crowd. And if they are poor, they can ask for alms from passersby.

In one prison I saw more than forty poor inmates walking around, crying for mercy. In another I saw imprisoned artisans seated at their workbenches and earning salaries despite their condition. In another cell I saw wealthy merchants playing dice and chess, their women standing outside the gates with their servants and slaves, talking to their husbands. In one private cell I saw a certain old Jew, incarcerated for debt, who had hung himself... [The guards] watched over many prisoners with much less caution, thereby offering many the opportunity to escape, especially when they notice that an inmate's adversary is unreasonably cruel . . . To be sure, those who are imprisoned for grave offenses and who are likely to receive a death penalty, are kept in stricter conditions, though they are tolerable. ${ }^{31}$

There is no reminiscence of the afterlife in this text, written, significantly, by a member of a religious order. Nonetheless, the description is idealized, conforming to the genre of wondrous travel narratives at the time. ${ }^{32}$ Yet, balancing Manenti's lugubrious poetry, the narrative testifies to the social and economic integration of the prison into medieval urban life. And it is this integration - the immediate presence of others in a prisoner's life and the latter's in the life of others - that may have prevented medieval captivity from becoming truly unbearable. Indeed, as brother Felix added, reflecting on the situation in his native land, "one of the many cruelties of the Germans is that the malefactors' prisons are inhuman, frightening and dark; located in the depths of towers, humid, cold and often crawling with snakes and toads; far apart from any humans. Nor does anyone arrive to comfort those 
miserable souls, other than the cruelest torturers." ${ }^{33}$ Medieval German prisons remain a major scholarly lacuna. But whether their characterization by Felix was real or ideal, from a broader regional perspective, it was precisely this type of prison that was gradually relinquishing its place.

This brief account of medieval prisons does not seek to move the prison's birth as a total institution five-hundred years back in time, nor to demonstrate the application of punitive imprisonment in the Middle Ages on a modern scale. Although fourteenth-century Europe saw a greater recourse to incarceration than it had ever known before, prisons were nowhere the basis of local penal systems; and despite the fact that these facilities served as important cogs in the administration of contemporary justice, they were never as regimented or enclosed as their modern counterparts. The organization of medieval prisons and their complementary accessibility ensured that, regardless of the grounds and goals of their incarceration, inmates continued to interact with surrounding society. Prison walls in the late Middle Ages did not describe the borders of a social island: their location, routine, and permeability prevents us from defining life inside as hell on earth, even if the perception of prisons as earthly purgatories had by then lost its favor.

\section{Notes}

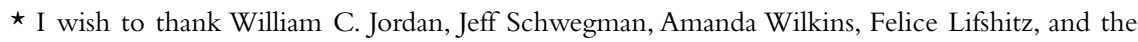
anonymous reviewers of History Compass for their critical eye and helpful suggestions. Unless otherwise indicated, translations are my own.

${ }^{1}$ M. Foucault, Discipline and Punish:The Birth of the Prison, trans. A. Sheridan (New York: Vintage Books, 1979); D. Melossi and M. Pavarini, The Prison and the Factory: Origins of the Penitentiary System, trans. G. Cousin (Totowa, NJ: Barnes and Noble, 1981); G. Rusche and O. Kirchenheimer, Punishment and Social Structure (New York: Columbia University Press, 1939); I. Taylor, P. Walton and J. Young, The New Criminology: For a Social Theory of Deviance (London/Boston: Routledge and Kegal Paul, 1973); B. Fine, "The Birth of Bourgeois Punishment," Crime and Social Justice, 13 (1980): 19-26. On the dating of prisons as penal/rehabilitative institutions to the late sixteenth century, see R. von Hippel, "Beiträge zur Geschichte der Freiheitsstrafe," Zeitschrift für die gesamte Strafrechtswissenschaften, 18 (1898): 419-94, 609-66; von Hippel, Strafrechtsreform und Strafzwecke (Göttingen: Vandenhoeck \& Ruprecht, 1907); A. Van der Slice, "Elizabethan Houses of Correction," Journal of Criminal Law and Criminology, 45 (1936-37): 45-67; R. Finzsch and R. Jütte (eds.), Institutions of Confinement. Hospitals, Asylums, and Prison in Western Europe and North America, 1500-1950 (Cambridge: Cambridge University Press, 1996), 3-35.

${ }^{2}$ E. Gallo and V. Ruggiero, Il carcere in europa (Verona: Bertani, 1983), 27.

${ }^{3}$ R. Pugh, Imprisonment in Medieval England (Cambridge: Cambridge University Press, 1968). Key earlier treatments of medieval English prisons include M. Bassett, "The Fleet Prison in the Middle Ages," The University of Toronto Law Journal, 5 (1944): 383-402; Bassett, "Newgate Prison in the Middle Ages," Speculum, 18 (1943): 233-46.

${ }^{4}$ M. Beltrani-Scalia, Sul governo e sulla riforma delle carceri in Italia. Saggio storico e teoretico (Turin: G. Gavale, 1867); S. Biffi, Sulle antiche carceri di Milano e del Ducato Milanese (Milan: C. Rebeschini, 1884); A. Bertolotti, "Prigioni e prigioneri in Mantova dal secolo XIII al secolo XIX," Bullettino ufficiale della Direzione Generale delle Carceri, 17 (1887): 51-70, 163-82; R. Laschi, "Pene e carceri nella storia di Verona," Atti del Reale Istituto Veneto di scienze, lettere ed arti, 64/2 (1904-05): 13 -93; G. Bohne, Die Freiheitsstrafe in den italienischen Stadtrechten des 12.-16. Jahrhunderts, 2 vols., Leipziger rechtswissenschatliche Studien Hft. 4, 9 (Leipzig: T. Weicher, 1922-25); G. Dahm, Das Strafrecht Italiens im ausgehanden Mittelalter, in M. Grünhut and E. Schmidt (eds.), Beiträge zur 
Geschichte der deutschen Strafrechtespflege, vol. 3 (Berlin/Leipzig: W. de Gruyter, 1931), 308-11; R. Grand, "La prison et la notion d'emprisonnement dans l'ancien droit," Revue historique de droit français et étranger, $4^{\text {th }}$ ser., 19-20/1-2 (1940-41): 58-87; Grand, "Justice criminelle: Procedure et peines dans les villes aux XIIIe et XIVe siècles," Bibliothèque de l'École des Chartes, 102 (1942): 51-108; U. Franzoi, Le prigioni della Repubblica di Venezia (Venice: Stamperia di Venezia Editrice, 1966); A. Porteau-Bitker, "L'emprisonnement dans le droit läque du moyen âge," Revue historique de droit français et étranger, 46/2 (1968): 211-45, 398-428; D. M. Nicholas, "Crime and Punishments in Fourteenth-Century Ghent," Revue belge de philology et d'histoire, 48/2 (1970): 289-334; 48/4 (1970): 1141-76; G. W. Coopland, "Crime and Punishment in Paris, September 6, 1389 to May 18, 1390," in S. A. Hanna (ed.), Medieval and Middle Eastern Studies in Honor of Aziz Suryal Atiya (Leiden: E. J. Brill, 1972), 64-85; P. R. Pazzaglini, "Comments on the Comparable Practices of Medieval Imprisonment," Studi Senesi, 86 (1974): 154-67; B. A. Hanawalt, Crime and Conflict in English Communities, 1300-1348 (Cambridge, MA: Harvard University Press, 1979), 53, 284; G. Scarabello, Carceri e Carcerati a Venezia nell'Età moderna (Rome: Instituto della Enciclopedia Italiana, 1979); M. Vincent-Cassy, "Prison et châtiments à la fin du Moyen Âge," in Les marginaux et les exclus dans l'histoire, Cahiers Jussieu no. 5 (Paris: Inédit, 1979), 262-74; R. W. Ireland, "Theory and Practice within the Medieval English Prison," The American Journal of Legal History, 31/1 (1987): 56-67; C. M. Small, "Prisoners in the Castellany of Artois in the Early Fourteenth Century," Histoire sociale - Social History, 26/52 (1993): 345-72; E. M. Peters, "Prison Before the Prison: The Ancient and Medieval Worlds," in N. Morris and D. J. Rothman (eds.), The Oxford History of the Prison. The Practice of Punishment in Western Society (New York/Oxford: Oxford University Press, 1995), 3-43; N. Gonthier, La châtiment du crime au Moyen Âge, XIIe-XVIe siècles (Rennes: Presses Universitaires de Rennes, 1998), 84-94, 114-20; T. Dean, Crime in Medieval Europe, 1200-1550 (Harlow: Longman, 2001), 120-24; J. Dunbabin, Captivity and Imprisonment in Medieval Europe, 1000-1300 (New York: Palgrave Macmillan, 2002); L. Fadalti, P. Sovernigo and M. Rebecca, Gli artigli del leone. Giustizia e carcere a Venezia dal XII al XVIII secolo (Treviso: Antilia, 2004); I. Mathieu,"Prisons et prisonniers en Anjou au bas Moyen Âge," Annales de Bretagne et des pays de l'Ouest, 112/1 (2005): 147-69. On imprisonment in Late Antiquity see T. Mommsen, Römisches Strafrecht (Leipzig: Duncker \& Humblot, 1899), 960- 63; A. H. J. Greenidge, The Legal Procedure of Cicero's Time (Oxford: Clarendon, 1901), 512-16; P. Garnsey, Social Status and Legal Privilege in the Roman Empire (Oxford: Clarendon, 1970), 147-52; F. Millar, "Condemnation to Hard Labour in the Roman Empire, from the Julio-Claudians to Constantine," Papers of the British Schools at Rome, 52 (1984): 128-47; J.-U. Krause, Gefängnisse im Römischen Reich (Stuttgart: F. Steiner, 1996); Krause, "Prisons et crimes dans l'Empire romain," in C. Bertrand-Dagenbach (ed.), Carcer: Prison et privation de liberté dans l'Antiquité classique. Actes du colloque de Strassburg (5 et 6 décembre 1997) (Paris: De Boccard, 1999), 117-28.

${ }^{5}$ See F. A. K. Krauss, Im Kerker vor und nach Christus (Freiburg/Leipzig: Mohr, 1895); Bohne, Freiheitsstrafe, 1:80-90, 232-79; Peters, "Prison Before the Prison," 22-30; N. Johnston, Forms of Constraint. A History of Prison Architecture (Urbana/Chicago: University of Illinois Press, 2000), 17-27. On penitential literature and monastic incarceration, see B. Poschmann, Die abendländische Kirchenbuße im frühen Mittelalter (Breslau: Müller \& Seiffert, 1930), 122-3; J. Mabillon, "Reflexions sur les prisons des ordres religieux," in V. Thuillier (ed.), Ouvrages posthumes de D. Jean Mabillon et D. Thirri Ruinart (Paris: F. Babuty, 1824), 321-35.

${ }^{6} \mathrm{~J}$. Chiffoleau, Les justices du Pape: Délinquance et criminalité dans la région d'Avignon au quatorzième siècle (Paris: Publications de la Sorbonne, 1984); J. B. Given, Inquisition and Medieval Society: Power, Discipline, and Resistance in Languedoc (Ithaca, NY: Cornell University Press, 1997).

${ }^{7}$ F. Graus, "Die Gewalt bei den Anfängen des Feudalismus und die 'Gefangenenbefreiungen' der merowingischen Hagiographie," Jahrbuch für Wirtschaftsgeschichte, 1 (1961): 61-156; S. D. Sargent, "Religion and Society in Late Medieval Bavaria: The Cult of St Leonard, 1258-1500," unpublished Ph.D. thesis (University of Pennsylvania, 1982); A. Wiesheu, "Bischof und Gefängnis. Zur Interpretation der Kerkerbefreiungswunder in der merowingischen Hagiographie," Historisches Zeitschrift, 121 (2001): 1-23.

${ }^{8}$ M. E. Wolfgang, "A Florentine Prison: Le Carceri delle Stinche," Studies in the Renaissance, 7 (1960): 148-66; H. Manikowska, "The Florentine Communal Prison - Le Stinche - in the Fourteenth Century," Acta Poloniae Historica, 71 (1995): 133-60.

${ }^{9}$ D. M. Nicholas, The Growth of the Medieval City. From Late Antiquity to the Early Fourteenth Century (London/New York: Longman, 1997). 
${ }^{10}$ F. Redi, "Dalla torre al palazzo: Forme abitative signorili e organizzazione dello spazio urbano a Pisa dall'IX al XV secolo," in Ceti dirigenti nella Toscana tardo comunale (Florence: F. Papafave, 1983), 271-96; P. Racine, "Les palais publics dans les communes italiennes (XII-XIIIe siècles)," in Le paysage urbain au Moyen-Age (Lyon: Presses Universitaires de Lyon, 1981), 133-53. And see A. I. Pini, Città, comuni e corporazioni nel medioevo italiano (Bologna: CLUEB, 1986), with ample bibliography.

${ }^{11}$ Nearly six hundred years after the prison became a sine qua non of urban space, we are witnessing its migration to the peripheries and rural hinterland. In other cases, the prison is simply camouflaged as a downtown hotel (as in Los Angeles) or as a non-descript government building (as in Philadelphia, Chicago, and New York). See M. Davis, City of Quartz. Excavating the Future of Los Angeles (New York: Vintage, 1992), 253-7; The Home Office, New Directions in Prison Design. Report of a Home Office Study of New Generation Prisons in the U.S.A. (London: HMSO, 1985), $8-19$.

${ }^{12}$ In his classic study, G. M. Sykes, The Society of Captives. A Study of a Maximum Security Prison (Princeton, NJ: Princeton University Press, 1958), 63-83, calculated that in one year merely forty-one percent of the 1,500 inmates in New Jersey's main prison facility received a visitor. For similar visitation rates (which improve over time) in Canadian prisons in the mid-1980s, see E. Zamble and F. J. Porporino, Coping, Behavior, and Adaptation in Prison Inmates (New York: Springer-Verlag, 1988), 81, 106; A. Cordilia, The Making of an Inmate. Prison as a Way of Life (Cambridge, MA: Schenkman, 1983), 31-46.

${ }^{13}$ J. Koenig," "Prisoner Offerings, Patron Saints and the State Cults at Siena and other Italian Cities from 1250 to 1550," Bullettino senese di storia patria, 108 (2001): 222-96

${ }^{14}$ J. A. F.Thomson, "Clergy and Laity in London, 1376-1531," unpublished DPhil thesis (Oxford University, 1960), 179. And see J. T. Rosenthal, The Purchase of Paradise: Gift Giving and the Aristocracy, 1307-1485 (London: Routledge and Kegan Paul, 1972), 109-110.

15 The term "total institution" was originally defined by E. Goffman, Asylums. Essays on the Social Situation of Mental Patients and Other Inmates (Garden City, NY: Anchor Books, 1961), xiii, "as a place of residence and work where a large number of like-situated individuals, cut off from the wider society for an appreciable period of time, together lead an enclosed, formally administered round of life."

16 The following observations are based on my own research on municipal prisons in central and northern Italy: G. Geltner, "Crime and the City Solution: The First Century of European Prisons, $c .1250-c .1400, " \mathrm{PhD}$ dissertation (Princeton University, in progress). In large part they confirm the findings of the aforementioned literature on France, England, and Italy.

17 Codex Theodosianus, ed. T. Mommsen and P. Meyer (Berlin: Weidmann, 1905), 9.3.1. The statement initially led Mommsen to conclude that the "Roman law did not know punitive incarceration" (Römisches Staatrecht, 2nd ed., 2 vols. [Leipzig: S. Hirzel, 1876-88], 1:149) - a view he and others later rejected.

${ }^{18}$ G. Penco "Monasterium - Carcer," Studia Monastica, 8 (1966): 133-43; J. Leclercq, "Le cloitre est-il une prison?" Revue d'ascetique et de mystique, 47 (1971): 407-20; J. M. Ferrante, "Images of the Cloister - Haven or Prison," Mediaevalia, 12 (1989 for 1986): 57-66; S. Greenblatt, Hamlet in Purgatory (Princeton, NJ/Oxford: Princeton University Press, 2001), 61-7.

${ }^{19}$ M. L. Menghetti, "Scrivere in carcere nel medioevo," in P. Frassica (ed.), Studi di filologia e letteratura italiani in onore di Maria Picchio Simonelli (Alessandia: Edizioni dell'Orso, 1992), 185-99.

${ }^{20}$ At one point, renovations at the upperVenetian prisons were deemed necessary since the present cells were "infecting the air and weakening the [prisoners'] bodies." See R. Cessi (ed.), Deliberazioni del Maggior Consiglio di Venezia, 3 vols. (Bologna: N. Zanichelli, 1931- 50), 3:428. Official documents relating the founding of new prison spaces are in G. Pamploni (ed.), Firenze al tempo di Dante. Documenti sull'urbanistica fiorentina (Rome: Ministro dell'Interno, 1973), nos. 25-6, 28-9; T. Dean (ed. and trans.), The Towns of Italy in the Later Middle Ages (Manchester/New York: Manchester University Press, 2000), 30-32 (on Venice).

${ }^{21}$ Dean, Towns of Italy, 25-27 (on Siena); G. Villani, Nuova cronica, ed. G. Porta, 3 vols. (Parma: Fondazione Pietro Bembo/U. Guanda, 1990-1), 1:442 (on Florence); L. de Monacis, Chronicon de rebus venetis (Venice: Remondini, 1758), book 14, p. 279 (on Venice).

22 The Florentine Le Stinche appears as an independent building in a plan of Florence from a manuscript of Ptolmey's Cosmographia by Pietro del Massaio, Biblioteca Apostolica Vaticana, Cod. Lat. 5699, f. 126v (1469). Another prison was depicted in a fresco of fourteenth-century 
Padua - possibly the first of its kind - which decorates the chapel of San Luca at the church dedicated to St. Anthony of Padua (Il Santo) in his native city. See A. Moschetti, "Gli affreschi della Cappella del b. Luca," Il Santo, 1/4 (1928):298. And see F. Ratté, "Re-Presenting the Common Place: Architectural Portraits in Trecento Painting," Studies in Iconography, 22 (2001): 87-110.

${ }^{23}$ Dean, Towns of Italy, 20. A discussion and edition of the text is in G. Fabris, "La cronaca di Giovanni da Nono," Bollettino del Museo civico di Padova, new ser. 10 (1932): 1-33; 11 (1933): 167-200; 12-17 (1934-39): 1-30.

${ }^{24}$ As a recent translator of Dante points out, current linguistic conventions obscure the fact that purgatory is essentially a good place to be in: Dante Alighieri, Purgatorio, trans. J. Hollander and R. Hollander (New York: Doubleday, 2003), xv.

${ }^{25}$ D. M. Manni, Le veglie piacevoli, 2nd ed. (Florence: 1815), 2:38-54.

${ }^{26}$ C. Mazzi, Il Burchiello (Bologna: 1879), 70-1.

27 Anonymous (ed.), Il primo libro del l'opere Burlesche di M. Francesco Berni (Florence: 1553), ff. $49 \mathrm{v}-53 \mathrm{r}$ at ff. $52 \mathrm{r}-53 \mathrm{r}$. Stooping was not an act of reverence: Le Stinche's gate was simply quite small. See F. Becchi, Sulle Stinche di Firenze e su'nuovi edifizi eretti in quel luogo (Florence: 1839).

28 Opera nuova in versi volgare, intitulata specchio de la giustizia (Venice: 1541). For on-line excerpts see http://digilander.libero.it/giovannidallorto/testi/ve/zm/zm.html.

${ }^{29}$ Laschi, "Pene e carceri nella storia di Verona," 46.

${ }^{30}$ F. Sacchetti, Il trecentonovelle, ed. V. Marucci (Rome: Salerno, 1996), 139:423-4. Another story - purportedly real - relates the 1486 entry of Pacchierotto, a known Florentine criminal and sodomite, into Le Stinche. See M. Rocke, Forbidden Friendships: Homosexuality and Male Culture in Renaissance Florence (New York/Oxford: Oxford University Press, 1996), 78.

31 C. D. Hassler (ed.), Fratris Felicis Fabri Evagatorium in Terrae Sanctae, Arabiae et Egyptii Peregrinationem, 3 vols. (Stuttgart: 1843-49), 2:409-10.

32 Z. von Martels (ed.), Travel Fact and Travel Fiction: Studies on Fiction, Literary Tradition, Scholarly Discovery and Observation in Travel Writing (Leiden/New York: E. J. Brill, 1994); J. P. Rubiés, "Travel Writing as a Genre: Facts, Fiction and the Invention of a Scientific Discourse in Early Modern Europe," Journeys. The International Journal of Travel and Travel Writing, 1/1-2 (2000): $5-35$.

${ }^{33}$ Hassler (ed.), Fratris Felicis Fabri, 2:410.

\section{Bibliography}

Alighieri, D., Purgatorio, trans. J. Hollander and R. Hollander (New York: Doubleday, 2003).

Anonymous (ed.), Il primo libro del l'opere Burlesche di M. Francesco Berni (Florence: 1553).

Barnes, H. E., and Teeters, N. K., New Horizons in Criminology, 2nd ed. (New York: Prentice-Hall, Inc., 1955).

Bassett, M., "Newgate Prison in the Middle Ages," Speculum, 18 (1943): 233-46.

Bassett, M., "The Fleet Prison in the Middle Ages," The University of Toronto Law Journal, 5 (1944): 383-402.

Becchi, F., Sulle Stinche di Firenze e su'nuovi edifizi eretti in quel luogo (Florence: 1839).

Beltrani-Scalia, M., Sul governo e sulla riforma delle carceri in Italia. Saggio storico e teoretico (Turin: G. Gavale, 1867).

Bertolotti,A., "Prigioni e prigioneri in Mantova dal secolo XIII al secolo XIX," Bullettino ufficiale della Direzione Generale delle Carceri, 17 (1887): 51-70, 163-82.

Biffi, S., Sulle antiche carceri di Milano e del Ducato Milanese (Milan: C. Rebeschini, 1884).

Bohne, G., Die Freiheitsstrafe in den italienischen Stadtrechten des 12.-16. Jahrhunderts, 2 vols., Leipziger rechtswissenschatliche Studien Hft. 4, 9 (Leipzig: T. Weicher, 1922-25).

Cessi, R. (ed.), Deliberazioni del Maggior Consiglio di Venezia, 3 vols. (Bologna: N. Zanichelli, 1931-50).

Chiffoleau, J., Les justices du Pape: délinquance et criminalité dans la région d'Avignon au quatorzième siècle (Paris: Publications de la Sorbonne, 1984).

Coopland, G. W., "Crime and Punishment in Paris, September 6, 1389 to May 18, 1390," in S. A. Hanna (ed.), Medieval and Middle Eastern Studies in Honor of Aziz Suryal Atiya (Leiden: E. J. Brill, 1972), 64-85.

Cordilia, A., The Making of an Inmate. Prison as a Way of Life (Cambridge, MA: Schenkman, 1983). 
Dahm, G., Das Strafrecht Italiens im ausgehanden Mittelalter, in M. Grünhut and E. Schmidt (eds.), Beiträge zur Geschichte der deutschen Strafrechtespflege, vol. 3 (Berlin and Leipzig: W. de Gruyter, 1931).

Davis, M., City of Quartz. Excavating the Future of Los Angeles (New York: Vintage, 1992).

Dean, T. (ed. and trans.), The Towns of Italy in the Later Middle Ages (Manchester/New York: Manchester University Press, 2000).

Dean, T., Crime in Medieval Europe, 1200-1550 (Harlow: Longman, 2001).

Dunbabin, J., Captivity and Imprisonment in Medieval Europe, 1000-1300 (New York: Palgrave Macmillan, 2002).

Fabris, G., "La cronaca di Giovanni da Nono," Bollettino del Museo civico di Padova, new ser. 10 (1932): 1-33; 11 (1933): 167-200; 12-17 (1934-39): 1-30.

Fadalti, L., Sovernigo, P., and Rebecca, M., Gli artigli del leone. Giustizia e carcere a Venezia dal XII al XVIII secolo (Treviso: Antilia, 2004).

Ferrante, J. M., "Images of the Cloister - Haven or Prison," Mediaevalia, 12 (1989 for 1986): 57-66.

Fine, B., "The Birth of Bourgeois Punishment," Crime and Social Justice, 13 (1980): 19-26.

Finzsch, R., and Jütte, R. (eds.), Institutions of Confinement. Hospitals, Asylums, and Prison in Western Europe and North America, 1500-1950 (Cambridge: Cambridge University Press, 1996).

Foucault, M., The Birth of the Clinic. An Archaeology of Medical Perceptions, trans. A. M. Sheridan Smith (New York: Pantheon Books, 1973).

Foucault, M., Discipline and Punish: Birth of the Prison, trans. A. Sheridan (New York: Vintage Books, 1979).

Franzoi, U., Le prigioni della Repubblica di Venezia (Venice: Stamperia di Venezia Editrice, 1966).

Gallo, E., and Ruggiero, V., Il carcere in europa (Verona: Bertani, 1983).

Garnsey, P., Social Status and Legal Privilege in the Roman Empire (Oxford: Clarendon, 1970).

Geltner, G., "Crime and the City Solution: The First Century of European Prisons, c.1250-c.1400," $\mathrm{PhD}$ dissertation (Princeton University, in progress).

Given, J. B., Inquisition and Medieval Society: Power, Discipline, and Resistance in Languedoc (Ithaca, NY: Cornell University Press, 1997).

Goffman, E., Asylums. Essays on the Social Situation of Mental Patients and Other Inmates (Garden City, NY: Anchor Books, 1961).

Gonthier, N., La châtiment du crime au Moyen Âge, XIIe-XVIe siècles (Rennes: Presses Universitaires de Rennes, 1998).

Grand, R., "La prison et la notion d'emprisonnement dans l'ancien droit," Revue historique de droit français et étranger, $4^{\text {th }}$ ser., 19-20/1-2 (1940-41): 58-87.

Grand, R., "Justice criminelle: Procedure et peines dans les villes aux XIIIe et XIVe siècles," Bibliothèque de l'École des Chartes, 102 (1942): 51-108.

Graus, F., 'Die Gewalt bei den Anfängen des Feudalismus und die "Gefangenenbefreiungen” der merowingischen Hagiographie,' Jahrbuch für Wirtschaftsgeschichte, 1 (1961): 61-156.

Greenblatt, S., Hamlet in Purgatory (Princeton, NJ/Oxford: Princeton University Press, 2001).

Greenidge, A. H. J., The Legal Procedure of Cicero's Time (Oxford: Clarendon, 1901).

Hanawalt, B.A., Crime and Conflict in English Communities, 1300-1348 (Cambridge, MA: Harvard University Press, 1979).

Hassler, C. D. (ed.), Fratris Felicis Fabri Evagatorium in Terrae Sanctae, Arabiae et Egyptii Peregrinationem, 3 vols. (Stuttgart: $1843-49)$.

von Hippel, R. "Beiträge zur Geschichte der Freiheitsstrafe," Zeitschrift für die gesamte Strafrechtswissenschaften, 18 (1898): 419-94, 609-66.

von Hippel, R., Strafrechtsreform und Strafzwecke (Göttingen: Vandenhoeck \& Ruprecht, 1907).

Home Office, New Directions in Prison Design. Report of a Home Office Study of New Generation Prisons in the U.S.A. (London: HMSO, 1985).

Ireland, R. W., "Theory and Practice within the Medieval English Prison," The American Journal of Legal History, 31/1 (1987): 56-67.

Johnston, N., Forms of Constraint. A History of Prison Architecture (Urbana/Chicago: University of Illinois Press, 2000).

Koenig, J., "Prisoner Offerings, Patron Saints and the State Cults at Siena and other Italian Cities from 1250 to 1550," Bullettino senese di storia patria, 108 (2001), 222-96.

Krause, J.-U., Gefängnisse im Römischen Reich (Stuttgart: F. Steiner, 1996). 
Krause, J.-U., "Prisons et crimes dans l'Empire romain,” in C. Bertrand-Dagenbach (ed.), Carcer: Prison et privation de liberté dans l'Antiquité classique. Actes du colloque de Strassburg (5 et 6 décembre 1997) (Paris: De Boccard, 1999), 117-28.

Krauss, F. A. K., Im Kerker vor und nach Christus (Freiburg/Leipzig: Mohr, 1895).

Laschi, R., "Pene e carceri nella storia di Verona," Atti del Reale Istituto Veneto di scienze, lettere ed arti, 64/2 (1904-05): 13-93.

Leclercq, J., “Le cloître est-il une prison?” Revue d'ascetique et de mystique, 47 (1971): 407-20.

Mabillon, J., "Reflexions sur les prisons des ordres religieux," in V. Thuillier (ed.), Ouvrages posthumes de D. Jean Mabillon et D. Thirri Ruinart (Paris: F. Babuty, 1824), 321-35.

Manenti, Z., Opera nuova in versi volgare, intitulata specchio de la giustizia (Venice: 1541).

Manikowska, H., "The Florentine Communal Prison - Le Stinche - in the Fourteenth Century," Acta Poloniae Historica, 71 (1995): 133-60.

Manni, D. M., Le veglie piacevoli, 2nd ed. (Florence: 1815).

von Martels, Z. (ed.), Travel Fact and Travel Fiction: Studies on Fiction, Literary Tradition, Scholarly Discovery and Observation in Travel Writing (Leiden/New York: E. J. Brill, 1994).

Mathieu, I., "Prisons et prisonniers en Anjou au bas Moyen Âge," Annales de Bretagne et des pays de l'Ouest, 112/1 (2005): 147-69.

Mazzi, C., Il Burchiello (Bologna: 1879).

Melossi, D., and Pavarini, M., The Prison and the Factory: Origins of the Penitentiary System, trans. G. Cousin (Totowa, NJ: Barnes and Noble, 1981).

Menghetti, M. L., "Scrivere in carcere nel medioevo," in P. Frassica (ed.), Studi di filologia e letteratura italiani in onore di Maria Picchio Simonelli (Alessandia: Edizioni dell'Orso, 1992), 185-99.

Millar, F., "Condemnation to Hard Labour in the Roman Empire, from the Julio-Claudians to Constantine," Papers of the British Schools at Rome, 52 (1984): 128-47.

Mommsen, T., Römisches Staatrecht, 2nd ed., 2 vols. (Leipzig: S. Hirzel, 1876-88).

Mommsen, T., Römisches Strafrecht (Leipzig: Duncker \& Humblot, 1899).

de Monacis, L., Chronicon de rebus venetis (Venice: Remondini, 1758).

Moschetti, A., "Gli affreschi della Cappella del b. Luca," Il Santo, $1 / 4$ (1928): 295-312.

Nicholas, D. M., "Crime and Punishments in Fourteenth-Century Ghent," Revue belge de philology et d'histoire, 48/2 (1970): 289-334; 48/4 (1970): 1141-76.

Nicholas, D. M., The Growth of the Medieval City. From Late Antiquity to the Early Fourteenth Century (London/New York: Longman, 1997).

Pamploni, G. (ed.), Firenze al tempo di Dante. Documenti sull'urbanistica fiorentina (Rome: Ministro dell'Interno, 1973).

Pazzaglini, P. R., "Comments on the Comparable Practices of Medieval Imprisonment," Studi Senesi, 86 (1974): 154-67.

Penco, G., “Monasterium - Carcer,” Studia Monastica, 8 (1966): 133-43.

Peters, E. M., "Prison Before the Prison: The Ancient and Medieval Worlds," in N. Morris and D. J. Rothman (eds.), The Oxford History of the Prison. The Practice of Punishment in Western Society (Oxford: Oxford University Press, 1995), 3-43.

Pini, A. I., Città, comuni e corporazioni nel medioevo italiano (Bologna: CLUEB, 1986).

Porteau-Bitker, A., "L'emprisonnement dans le droit laïque du moyen âge," Revue historique de droit français et étranger, 46/2 (1968): 211-45, 398-428.

Poschmann, B., Die abendländische Kirchenbuße im frühen Mittelalter (Breslau, Müller \& Seiffert, 1930).

Pugh, R., Imprisonment in Medieval England (Cambridge: Cambridge University Press, 1968).

Racine, P., "Les palais publics dans les communes italiennes (XII-XIIIe siècles)," Le paysage urbain au Moyen-Age (Lyon: Presses Universitaires de Lyon, 1981), 133-53.

Ratté, F., "Re-Presenting the Common Place: Architectural Portraits in Trecento Painting," Studies in Iconography, 22 (2001): 87-110.

Redi, F., "Dalla torre al palazzo: Forme abitative signorili e organizzazione dello spazio urbano a Pisa dall'IX al XV secolo," in Ceti dirigenti nella Toscana tardo comunale (Florence: F. Papafave, 1983), 271-96.

Rocke, M., Forbidden Friendships: Homosexuality and Male Culture in Renaissance Florence (New York/Oxford: Oxford University Press, 1996).

Rosenthal, J. T., The Purchase of Paradise: Gift Giving and the Aristocracy, 1307-1485 (London: Routledge and Kegan Paul, 1972). 


\section{Medieval Prisons}

Rubiés, J. P., “Travel Writing as a Genre: Facts, Fiction and the Invention of a Scientific Discourse in Early Modern Europe," Journeys. The International Journal of Travel and Travel Writing, 1/1-2 (2000): 5-35.

Rusche, G., and Kirchenheimer, O., Punishment and Social Structure (New York: Columbia University Press, 1939).

Sacchetti, F., Il trecentonovelle, ed.V. Marucci (Rome: Salerno, 1996).

Sargent, S. D., "Religion and Society in Late Medieval Bavaria: The Cult of St Leonard, 1258-1500," unpublished PhD thesis (University of Pennsylvania, 1982).

Scarabello, G., Carceri e Carcerati a Venezia nell'Età moderna (Rome: Instituto della Enciclopedia Italiana, 1979).

Small, C. M., "Prisoners in the Castellany of Artois in the Early Fourteenth Century," Histoire sociale Social History, 26/52 (1993): 345-72.

Sykes, G. M., The Society of Captives. A Study of a Maximum Security Prison (Princeton, NJ: Princeton University Press, 1958).

Taylor, I., Walton, P., and Young, J., The New Criminology: For a Social Theory of Deviance (London/Boston: Routledge and Kegal Paul, 1973).

Thomson, J. A. F., “Clergy and Laity in London, 1376-1531," unpublished DPhil thesis (Oxford University, 1960).

Van der Slice, A. "Elizabethan Houses of Correction," Journal of Criminal Law and Criminology, 45 (1936-37): 45-67.

Villani, G., Nuova cronica, ed. G. Porta, 3 vols. (Parma: Fondazione Pietro Bembo/U. Guanda, 1990-1).

Vincent-Cassy, M., "Prison et châtiments à la fin du Moyen Âge," in Les marginaux et les exclus dans l'histoire, Cahiers Jussieu no. 5 (Paris: Inédit, 1979), 262-74.

Wiesheu, A., "Bischof und Gefängnis. Zur Interpretation der Kerkerbefreiungswunder in der merowingischen Hagiographie," Historisches Zeitschrift, 121 (2001): 1-23.

Wolfgang, M. E., “A Florentine Prison: Le Carceri delle Stinche,” Studies in the Renaissance, 7 (1960): 148-66.

Zamble, E., and Porporino, F. J., Coping, Behavior, and Adaptation in Prison Inmates (New York: Springer-Verlag, 1988). 